\title{
Aplikasi Fuzzy Goal Programming (Studi Kasus: UD. Sinar Sakti Manado)
}

\author{
Felliks F. Tampinongkol ${ }^{1}$, Altien J. Rindengan ${ }^{2}$, Luther A. Latumakulita ${ }^{3}$ \\ ${ }^{1}$ Program Studi Matematika, FMIPA, UNSRAT Manado, fftampinongkol09@gmail.com \\ ${ }^{2}$ Program Studi Matematika, FMIPA, UNSRAT Manado, altien@unsrat.ac.id \\ ${ }^{3}$ Program Studi Matematika, FMIPA, UNSRAT Manado, latumakulitala@unsrat.ac.id
}

\begin{abstract}
Abstrak
Pengoptimalan merupakan salah satu proses penentuan tinggi rendah-nya suatu pendapatan atau memaksimumkan keuntungan, meminimumkan tenaga kerja sesuai dengan yang diinginkan oleh pengambil keputusan. Penentuan solusi optimal sering kali dipakai oleh sebuah perusahaan atau organisasi yang bergerak dibidang pemasaran atau produksi untuk memperoleh informasi yang dibutuhkan. Tujuan dari penelitian ini adalah membuat user interface (UI) untuk menyelesaikan masalah fuzzy goal programming (FGP) dan penentuan hasil solusi optimal pada perusahaan UD. Sinar Sakti Manado. Data yang digunakan merupakan data hasil produksi perusahaan pada tahun 2014. Dari hasil yang diperoleh, jika pengambil keputusan perusahaan menginginkan pendapatan minimum Rp. 250.000.000 dan waktu kerja maximum 2400 jam, maka keuntungan yang akan diperoleh perusahaan sebesar Rp. 318.816 .650 dengan produk yang harus dihasilkan adalah 2 buah Dresoar uk.250, 28,7646 buah Dresoar uk.150, 2 buah Dresoar uk.100 dan 24,1966 set Sofa Laminating.
\end{abstract}

Kata kunci : Fuzzy Goal Programming, Optimalisasi, User Interface

\section{Application Of Fuzzy Goal Programming (Case Study: UD. Sinar Sakti Manado)}

\begin{abstract}
Optimization is a process of determining low height of revenue or profit maximization, minimizing labor in accordance with the objectives assigned by the decision makers. Determination of the optimal solution is often used by a company or organization running in marketing or production to obtain the information needed. The purpose of this research is to create a user interface (UI) to solve of fuzzy goal programming (FGP) problem and the determination of the optimal solution obtained in UD. Sinar Sakti Manado. The data used is moduction output data from the company in 2014. From the results obtained, if corporate decision makers wants a minimum income of Rp. 250.000 .000 and the maximum working time of 2400 hours, then the gains of company is Rp. 318.816.650 with the products to be produced is 2 pieces Dresoar size 250, 28.7646 pieces Dresoar size 150, 2 pieces Dresoar size 100 and 24.1966 set Sofa Laminating.
\end{abstract}

Keywords : Fuzzy Goal Programming, Optimization, User Interface

\section{Pendahuluan}

Dalam mencari solusi optimum menggunakan FGP diperlukan sebuah proses perhitungan yang panjang, pengambil keputusan harus memodelkan permasalahan agar dapat dianalisa dengan menentukan tujuan serta kendala yang ada. Sehingga untuk menentukan solusi dengan perhitungan manual akan memakan waktu yang cukup lama. Penentuan solusi optimal dengan metode FGP dapat dirancang dalam sebuah aplikasi yang akan mempermudah perhitungan secara manual dan juga dapat memberikan informasi yang cepat dan akurat. Sampai saat ini penelitian yang membuat program aplikasi dengan menggunakan metode fuzzy goal programming (FGP) masih jarang ditemukan. Beberapa penelitian terdahulu yang pernah dilakukan menggunakan metode FGP antara lain, Pendekatan Model Fuzzy Goal Programming dalam Penetapan Pembobotan Prioritas dari Metode Analytical Hierarchy Process (AHP) yang dilakukan di USU Medan bertujuan untuk pembobotan AHP dan dikembangkan menjadi model GP dan FGP [1]. Pada tahun 2013 penelitian tentang Fuzzy Goal Programming pada Perencanaan Produksi Aggregate (Studi Kasus pada UD. Charisma Kota Mojokerto) [2]. Selanjutnya penelitian tentang FGP yang berjudul Model Fuzzy 
Goal Programming yang diselesaikan dengan Linear Programming pada Perencanaan Produksi yang bertujuan untuk menyelesaikan masalah optimalisasi model FGP dengan menggunakan metode simpleks yang ada pada LP [3].

Pada penelitian ini model Fuzzy Goal Programming (FGP) akan dirancang dalam sebuah aplikasi yang dapat digunakan untuk penentuan solusi optimal, kasus yang diambil merupakan masalah produksi mebel dan furniture pada perusahaan UD. Sinar Sakti Kota Manado. Perusahaan UD. Sinar Sakti berdiri pada tahun 2005 dan bergerak dibidang produksi mebel dan lainnya. Belum ada penelitian sebelumnya yang dilakukan pada perusahaan UD. Sinar Sakti untuk penentuan perencanaan produksi menggunakan model fuzzy goal programming, apalagi sampai membuat sebuah sistem aplikasi yang dapat membantu memberikan informasi tentang solusi optimal yang diperoleh dari model fuzzy goal programming.

\section{Linear Programming}

Persoalan linear programming ialah suatu persoalan untuk memecahkan suatu persamaan dengan suatu tujuan tertentu dengan memperhatikan pembatasan-pembatasan yang ada [4].

Persoalan linear programming menyangkut 3 hal pokok yaitu :

1. Memecahkan persamaan, yaitu mencari nilai dari variabel keputusan $x_{1}, x_{2}, \ldots, x_{n}$.

2. Mencapai suatu tujuan, misalnya membuat fungsi objektif untuk maximum/minimum, misalkan $Z=p_{1} x_{1}+p_{2} x_{2}+\cdots+p_{n} x_{n}=$ maximum atau minimum.

3. Pembatasan-pembatasan yang ada, misalnya adanya bahan mentah yang terbatas, jumlah machine hours yang terbatas, modal terbatas dan sebagainya, katakan pembatas itu sebagai berikut :

$$
\begin{gathered}
a_{11} x_{1}+a_{12} x_{2}+\cdots+a_{1 n} x_{n} \leq h_{1} \\
a_{21} x_{1}+a_{22} x_{2}+\cdots+a_{2 n} x_{n} \leq h_{2} \\
\vdots \\
a_{n} x_{n}+a_{n} x_{n}+\cdots+a_{n} x_{n} \leq h_{m}
\end{gathered}
$$

Terdapat dua metode penyelesaian yang dapat digunakan dalam menyelesaikan masalah linear programming, yaitu :

- Metode grafik (untuk 2 variabel keputusan).

- Metode simpleks (untuk 2 atau lebih variabel keputusan).

\section{Fungsi Keanggotaan Fuzzy}

Fungsi keanggotaan (membership function) adalah suatu kurva yang menunjukkan pemetaan titik-titik input data kedalam nilai keanggotaanya (derajat keanggotaan) yang memiliki interval antara 0 sampai 1 [5].

- Representasi Linear

Pada representasi linear, pemetaan input ke derajat keanggotaanya digambarkan sebagai suatu garis lurus. Terdapat dua keadaan himpunan fuzzy yang linear:

Pertama, kenaikan himpunan dimulai pada nilai domain yang memiliki derajat keanggotaan nol [0] bergerak ke kanan menuju ke nilai domain yang memiliki derajat keanggotaan yang lebih tinggi seperti pada Gambar 1.

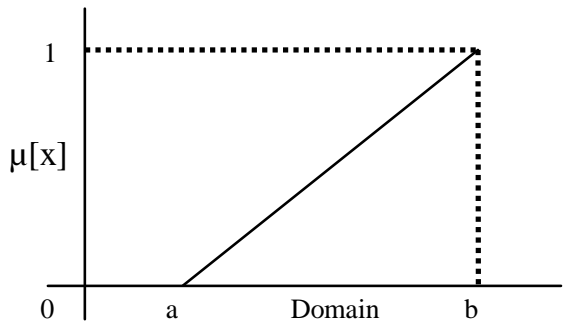

Gambar 1. Representasi Linear Naik

Fungsi Keanggotaan $: \mu[x]=\left\{\begin{array}{cl}0 ; & x<a \\ (x-a) /(b-a) ; & a \leq x \leq b \\ 1 ; & x>b\end{array}\right.$ 
Kedua, merupakan kebalikan yang pertama. Garis lurus dimulai dari nilai domain dengan derajat keanggotaan tertinggi pada sisi kiri, kemudian bergerak menurun ke nilai domain yang memiliki derajat keanggotaan lebih rendah seperti pada Gambar 2.

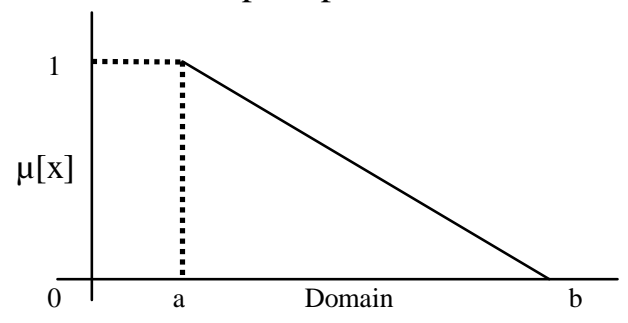

Gambar 2. Representasi Linear Turun

$$
\text { Fungsi Keanggotaan }: \mu[x]=\left\{\begin{array}{cll}
1 & ; \quad & x<a \\
(b-x) /(b-a) ; & a \leq x \leq b \\
0 \quad ; \quad & x>b
\end{array}\right.
$$

\section{Fuzzy Goal Programming}

Metode yang menggunakan himpunan fuzzy pada Goal Programming (GP) disebut Fuzzy Goal Programming (FGP), dimana metode ini tidak perlu melakukan kalibrasi pembobotan atau melakukan seleksi terhadap derajat pentingnya fungsi objektif. Metode ini hanya menggunakan preferensi khusus pada tujuan yang dapat dimodelkan dengan menggunakan fungsi-fungsi keanggotaan fuzzy. FGP ini, diformulasikan menjadi bentuk Linear Programming (LP) untuk mencari solusi optimalnya [3].

Secara matematis FGP dapat diformulasikan sebagai berikut :

Jika didefinisikan $x=\left[x_{1}, x_{2}, \ldots, x_{n}\right]^{T} \in R^{n}$ sebagai vektor variabel keputusan dan $f(x)=\left(f_{1}(x), f_{2}(x), \ldots, f_{m}(x)\right)$ adalah sebagai fungsi tujuan dengan bentuk kendala $G(x)$. Pengambil keputusan menginginkan batasan $f_{i}^{*},(i=1,2, \ldots, m)$ untuk setiap fungsi tujuan yang memenuhi kendala linear $G(x)$. Dengan menggunakan himpunan fuzzy, fungsi keanggotaan dapat didefinisikan berdasarkan langkah berikut :

1. Nyatakan

$$
\operatorname{Max} f_{i}(x), i=1,2, \ldots, m
$$

Dengan kendala $x \in G(x) \in R^{n}$

Misalkan diperoleh $x_{j}^{*}(j=1,2, \ldots, n)$ adalah solusi optimal pada fungsi tujuan $f_{i}(x)$, ambil $f_{i}\left(x_{j}^{*}\right)=f_{i \max }$

2. Tentukan Min $f_{i}\left(x_{j}^{*}\right)=f_{i \text { min }}$ untuk setiap $i$.

3. Definisikan fungsi keanggotaan fuzzy $\mu_{f i}(x),(i=1,2, \ldots, m)$ dalam bentuk :

$$
\mu_{f_{i}(x)}=\left\{\begin{array}{cc}
\frac{f_{\text {imax }}-f_{i}(x)}{f_{i \max }-f_{i}^{*}}, & f_{i}^{*}<f_{i}(x) \leq f_{i \max } \\
1, & f_{i}(x)=f_{i}^{*} \\
\frac{f_{i}(x)-f_{i \min }}{f_{i}^{*}-f_{i \min }}, & f_{i \min } \leq f_{i}(x)<f_{i}^{*}
\end{array}\right.
$$

Definisikan himpunan $F(\lambda, x)$, sehingga membentuk model FGP yaitu dengan menentukan $x^{*}$ yang memenuhi.

$\operatorname{Max} \lambda$

Dengan kendala $x \in F(\lambda, x) \cap G(x)$

Dimana $F(\lambda, x)=F^{\lambda}(x)=F_{1}^{\lambda} \cap \ldots \cap F_{i}^{\lambda} \ldots \cap F_{m}^{\lambda}$

Dengan $F_{i}^{\lambda}(x)=\left\{x \mid \mu_{f i}(x) \geq \lambda ; 0 \leq \lambda \leq 1, x \in F_{i}(x)\right\}$

Karena fungsi tujuan dalam model yang akan dibahas adalah masalah maksimisasi dan minimisasi, FGP dapat dinyatakan : 
Tentukan $x$

Sedemikian sehingga $F_{i}(\boldsymbol{x}) \leq f_{i}$ atau $F_{i}(\boldsymbol{x}) \geq f_{i}(i=1,2, \ldots, m)$

Dengan kendala $\boldsymbol{A} \boldsymbol{x} \leq \boldsymbol{b}, \boldsymbol{x} \geq 0$

dimana :

$F_{i}(\boldsymbol{x})=$ merupakan fungsi tujuan ke- $i$

$f_{i} \quad=$ level aspirasi dari fungsi tujuan $F_{i}(\boldsymbol{x})$

$\boldsymbol{A}=$ matriks koefisien untuk menghasilkan satu nilai variabel keputusan $x_{j}$

$\boldsymbol{b} \quad=$ adalah vektor kolom sisi kanan kendala.

Model FGP dapat dinyatakan dalam bentuk :

Tentukan $x^{*}$ yang memenuhi,

$\operatorname{Max} \lambda$

dengan kendala :

$$
\mu_{f i}(x) \geq \lambda
$$

$$
\boldsymbol{A x} \leq \boldsymbol{b}, \boldsymbol{x} \geq 0
$$

Sehingga fungsi keanggotaa fuzzy dari tiap fungsi tujuan adalah :

$\mu_{f_{i}(x)}=\left\{\begin{array}{cc}1, & F_{i}(x) \leq f_{i \text { min }} \\ \frac{U_{i}-F_{i}(x)}{U_{i}-f_{i \min }}, & f_{i \text { min }} \leq F_{i}(x) \leq U_{i} \\ 0, & F_{i}(x) \geq U_{i}\end{array}\right.$

$\mu_{f_{i}(x)}=\left\{\begin{array}{cc}1, & F_{i}(x) \geq f_{i \max } \\ \frac{F_{i}(x)-L_{i}}{f_{i \max }-L_{i}}, & L_{i} \leq F_{i}(x) \leq f_{i \max } \\ 0, & F_{i}(x) \leq L_{i}\end{array}\right.$

dimana $U_{i}$ dan $L_{i}$ merupakan batas atas dan bawah preferensi pangambil keputusan yang diinginan, $f_{i}$ adalah batasan optimal ( $\mathrm{max} / \mathrm{min}$ ) dari model.

Bentuk dari fungsi keanggotaan persamaan di atas dapat digambarkan sebagai berikut :

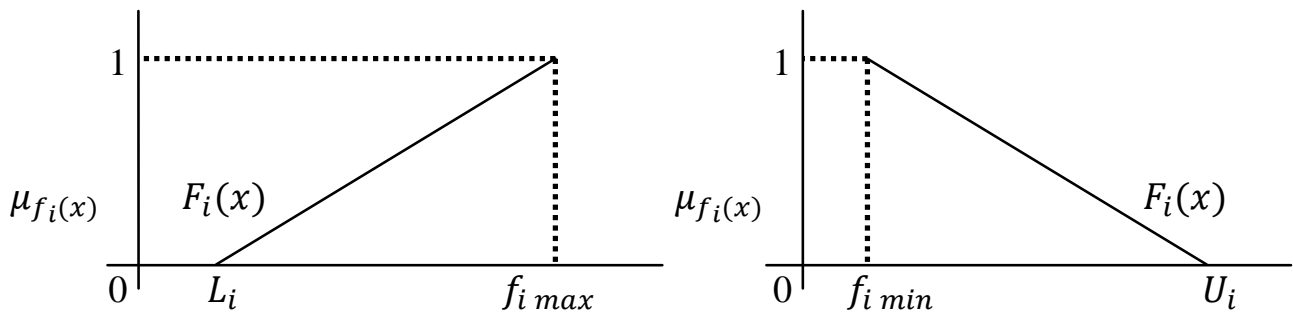

Gambar 3. Bentuk fungsi keanggotaa fuzzy linear naik dan turun

\section{Metodologi Penelitian}

Data yang digunakan dalam penelitian ini adalah data sekunder, yang diperoleh dari perusahaan mebel dan furniture UD. Sinar Sakti Manado. Data yang diambil merupakan data hasil produksi pada tahun 2014.

Tahapan Penelitian :

1) Formulasi Model Fuzzy Goal Programming (FGP)

- Menetapkan variabel-variabel keputusan

- Menetapkan bentuk-bentuk kendala

- Model linear programming (LP)

- Fungsi keanggotaan fuzzy

- Model FGP

- Aplikasi FGP

2) Desain Program Aplikasi 


\section{Hasil dan Pembahasan}

\subsection{Data Produksi UD. Sinar Sakti}

Data yang diperoleh merupakan data sekunder hasil produksi perusahaan mebel dan furniture UD. Sinar Sakti pada tahun 2014 seperti pada tabel 1 dan 2.

Tabel 1. Data yang diperoleh dari perusahaan mebel UD. Sinar Sakti

\begin{tabular}{|c|c|c|c|c|c|}
\hline \multirow{2}{*}{ No } & \multirow{2}{*}{ Nama Produk } & \multirow{2}{*}{$\begin{array}{l}\text { Harga / Unit } \\
\text { (Rp) }\end{array}$} & \multicolumn{2}{|c|}{ Bahan Baku Yang Terpakai } & \multirow{2}{*}{$\begin{array}{c}\text { Cat } \\
\text { (Liter) }\end{array}$} \\
\hline & & & Kayu (m3) & Jam Kerja & \\
\hline 1 & Dresoar Uk.250 ; 9 Buah & 7.500 .000 & 1,298 & 144 & 27 \\
\hline 2 & Dresoar Uk.150 ; 9 Buah & 4.500 .000 & 0,7788 & 86,4 & 22,5 \\
\hline 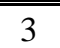 & Dresoar Uk.100 ; 9 Buah & 2.500 .000 & 0,5192 & 57,6 & 13,5 \\
\hline 4 & Kursi Makan ; 30 Buah & 800.000 & 0,381 & 224 & 15 \\
\hline 5 & Meja Makan Bulat ; 1 Buah & 4.900 .000 & 0,08 & 80 & 2 \\
\hline 6 & Sofa Laminating ; 10 Set & 7.000 .000 & 0,578 & $\overline{576}$ & 15 \\
\hline & & Total : & 3,635 & 1168 & 95 \\
\hline
\end{tabular}

Tabel 2. Data yang telah diolah untuk memperoleh informasi per satuan produk

\begin{tabular}{|c|c|c|c|c|c|}
\hline \multirow{2}{*}{ No } & \multirow{2}{*}{ Nama Produk } & \multirow{2}{*}{$\begin{array}{l}\text { Harga / Unit } \\
\text { (Rp) }\end{array}$} & \multicolumn{2}{|c|}{ Bahan Baku Yang Terpakai } & \multirow{2}{*}{$\begin{array}{c}\text { Cat } \\
\text { (Liter) }\end{array}$} \\
\hline & & & Kayu (m3) & Jam Kerja & \\
\hline 1 & Dresoar Uk.250 ; 1 Buah & 7.500 .000 & 0,1442 & 16 & 3 \\
\hline 2 & Dresoar Uk.150 ; 1 Buah & 4.500 .000 & 0,0865 & 9,6 & 2,5 \\
\hline 3 & Dresoar Uk.100 ; 1 Buah & 2.500 .000 & 0,0576 & 6,4 & 1,5 \\
\hline 4 & Kursi Makan ; 1 Buah & 800.000 & 0,0127 & 7,467 & 0,5 \\
\hline$\overline{5}$ & Meja Makan Bulat ; 1 Buah & 4.900 .000 & 0,08 & 80 & 2 \\
\hline 6 & Sofa Laminating ; 1 Set & 7.000 .000 & 0,0578 & 57,6 & 1,5 \\
\hline & & Total : & 0,4388 & 177,067 & 11 \\
\hline
\end{tabular}

Perusahaan juga menyaratkan produksi minimum untuk beberapa produk yaitu : membuat 2 buah Dresoar uk. 250, 2 buah Dresoar uk.150, 2 buah Dresoar uk. 100 dan 1 set Sofa laminating.

\subsection{Formulasi Model FGP Produksi UD. Sinar Sakti}

\subsubsection{Variabel Keputusan}

Variabel-variabel keputusan adalah jumlah produksi masing-masing produk yang dihasilkan UD. Sinar Sakti yaitu :

$x_{1}=$ Jumlah Dresoar Kayu Kelapa uk. 250

$x_{2}=$ Jumlah Dresoar Kayu Kelapa uk. 150

$x_{3}=$ Jumlah Dresoar Kayu Kelapa uk. 100

$x_{4}=$ Jumlah Kursi Makan

$x_{5}=$ Jumlah Meja Makan Bulat

$x_{6}=$ Jumlah Sofa Laminating

\subsubsection{Fungsi Tujuan}

Fungsi tujuan yang pertama akan dianalisa adalah maksimumkan pendapatan yang diinginkan oleh perusahaan disimbolkan $Z(x)$ seperti pada persamaan (6), harga jual tiap produk berdasarkan pada (Tabel 2) di sederhanakan menjadi 75, 45, 25, 8, 49 dan 70.

$\operatorname{Max} Z(x)=75 x_{1}+45 x_{2}+25 x_{3}+8 x_{4}+49 x_{5}+70 x_{6}$ 
Fungsi tujuan yang kedua adalah meminimumkan waktu kerja buruh yang disimbokan dengan $H(x)$ seperti pada persamaan (7) dan data dari (Tabel 2).

Min $H(x)=16 x_{1}+9,6 x_{2}+6,4 x_{3}+7,467 x_{4}+80 x_{5}+57,6 x_{6}$

\subsubsection{Bentuk Kendala}

Kendala yang ada berhubungan dengan bahan baku kayu, cat (fernis), keinginan perusahaan untuk memproduksi minimal 2 buah Dresoar uk. 250, 2 buah Dresoar uk. 150, 2 buah Dresoar uk. 100, dan 1 set sofa laminating. Model kendala dapat dilihat pada persamaan (8).

K. Kelapa : 0,1442 $x_{1}+0,0865 x_{2}+0,0576 x_{3}+0,0127 x_{4}+0,08 x_{5}+0,0578 x_{6} \leq 4,2905$

Cat/Fernis : $3 x_{1}+2,5 x_{2}+1,5 x_{3}+0,5 x_{4}+2 x_{5}+1,5 x_{6} \leq 340$

2 Dr uk.250: $x_{1} \quad \geq 2$

2 Dr uk.150: $\quad x_{2} \quad \geq 2$

2 Druk.100: $\quad x_{3} \quad \geq 2$

1 Set Sofa : $\quad x_{6} \geq 1$

\subsubsection{Model Linear Programming}

Berdasarkan persamaan (6), (7), (8) dan (Tabel 2) untuk tujuan maximumkan pendapatan, dan minimumkan waktu kerja buruh, model linear programming dapat dinyatakan sebagai berikut :

Fs. Tujuan

$\operatorname{Max} Z(x)=75 x_{1}+45 x_{2}+25 x_{3}+8 x_{4}+49 x_{5}+70 x_{6}$

Min $H(x)=16 x_{1}+9,6 x_{2}+6,4 x_{3}+7,467 x_{4}+80 x_{5}+57,6 x_{6}$

Fs. Kendala

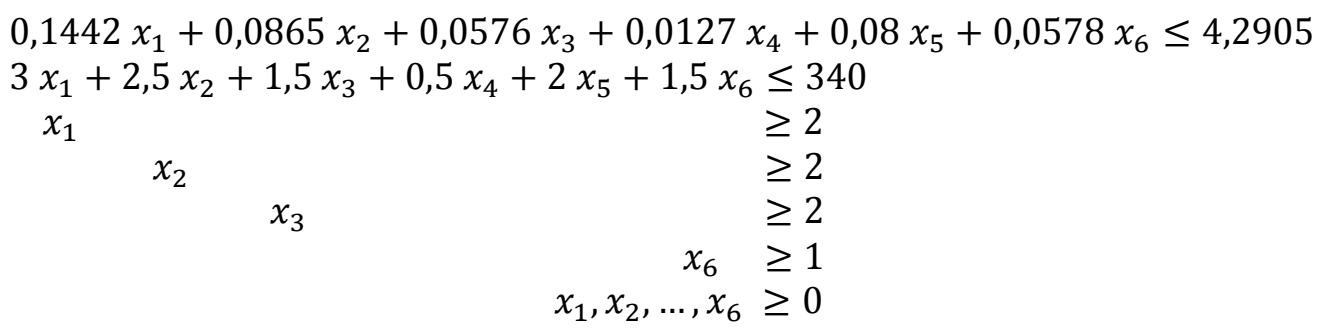

\subsubsection{Fungsi Keanggotaan Fuzzy}

Fungsi keanggotaan fuzzy dibentuk dari solusi optimal yang diperoleh dari hasil analisa LP dan berdasarkan preferensi pengambil keputusan.

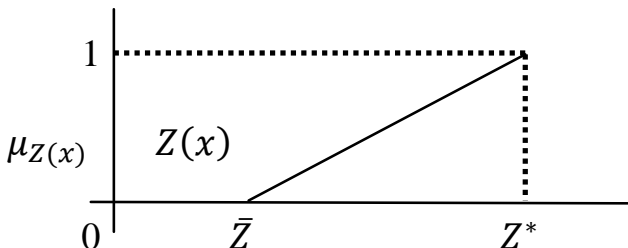

Gambar 6. Fungsi Keanggotaan Linear Naik

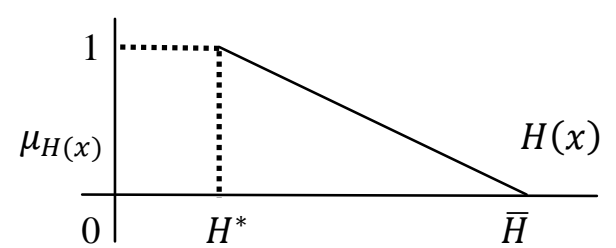

Gambar 7. Fungsi Keanggotaan Linear Turun

Fungsi keanggotaan fuzzy untuk tujuan maximum adalah:

$$
\mu_{Z(x)}=\left\{\begin{array}{cc}
1 ; & Z(x) \geq Z^{*} \\
(Z(x)-\bar{Z}) /\left(Z^{*}-\bar{Z}\right) ; & \bar{Z} \leq Z(x) \leq Z^{*} \\
0 ; & Z(x) \leq \bar{Z}
\end{array}\right.
$$

Fungsi keanggotaan fuzzy untuk tujuan minimum adalah:

$$
\mu_{H(x)}=\left\{\begin{array}{cc}
1 ; & H(x) \leq H^{*} \\
(\bar{H}-H(x)) /\left(\bar{H}-H^{*}\right) ; & H^{*} \leq H(x) \leq \bar{H} \\
0 ; & H(x) \geq \bar{H}
\end{array}\right.
$$


dengan

$Z^{*} \quad=$ Solusi pendapatan optimum dari linear programming

$\bar{Z} \quad=$ Pendapatan terendah yang diinginkan pengambil keputusan

$H^{*} \quad=$ Solusi minimum waktu kerja buruh dari linear programming

$\bar{H} \quad=$ Waktu kerja maximum yang diinginkan pengambil keputusan

\subsubsection{Model FGP}

Setelah ditentukan solusi dari masing-masing tujuan mana yang dinyatakan dalam fungsi keanggotaan fuzzy, maka dibuat model FGP. Model ini akan menjadi model dengan satu tujuan yang dapat dianalisa seperti model linear programming (LP).

Untuk $\mu_{Z(x)} \geq \lambda$ dengan $\mu_{Z(x)}=\frac{Z(x)-\bar{Z}}{Z^{*}-\bar{Z}}$ pada selang $\bar{Z} \leq Z(x) \leq Z^{*}$, dimana $\bar{Z}$ dan $Z^{*}$ bernilai real, berlaku : $Z(x)-\left(Z^{*}-\bar{Z}\right) \lambda \geq \bar{Z}$

$a_{11} x_{1}+a_{12} x_{2}+a_{13} x_{3}+a_{14} x_{4}+a_{15} x_{5}+a_{16} x_{6}-\left(Z^{*}-\bar{Z}\right) \lambda \geq \bar{Z}$

Untuk $\mu_{H(x)} \geq \lambda$ dengan $\mu_{H(x)}=\frac{\bar{H}-H(x)}{\bar{H}-H^{*}}$ pada selang $H^{*} \leq H(x) \leq \bar{H}$, dimana $\bar{H}$ dan $H^{*}$ bernilai real, berlaku : $H(x)+\left(\bar{H}-H^{*}\right) \lambda \leq \bar{H}$

$b_{11} x_{1}+b_{12} x_{2}+b_{13} x_{3}+b_{14} x_{4}+b_{15} x_{5}+b_{16} x_{6}+\left(\bar{H}-H^{*}\right) \lambda \leq \bar{H}$

Model FGP yang diperoleh adalah :

$\operatorname{Max} \lambda$

dengan kendala

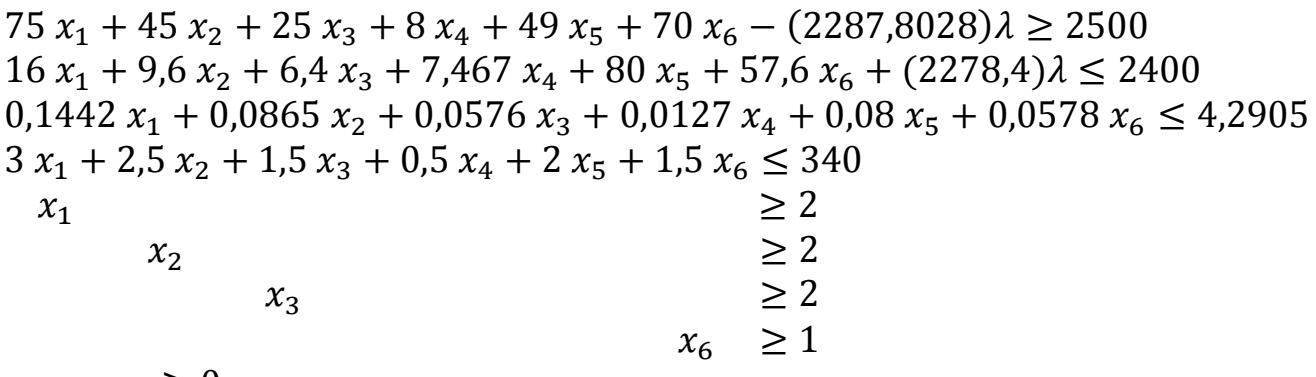

$x_{1}, \ldots, x_{6} \geq 0$

\subsection{Aplikasi Fuzzy Goal Programming}

\subsubsection{Interface Model Linear Programming}

Perhitungan menggunakan software matematika dengan membuat sebuah user interface yang dirancang melalui editor pada software tersebut. Model interface untuk menentukan solusi optimum dari linier programming dapat dilihat pada gambar 8.

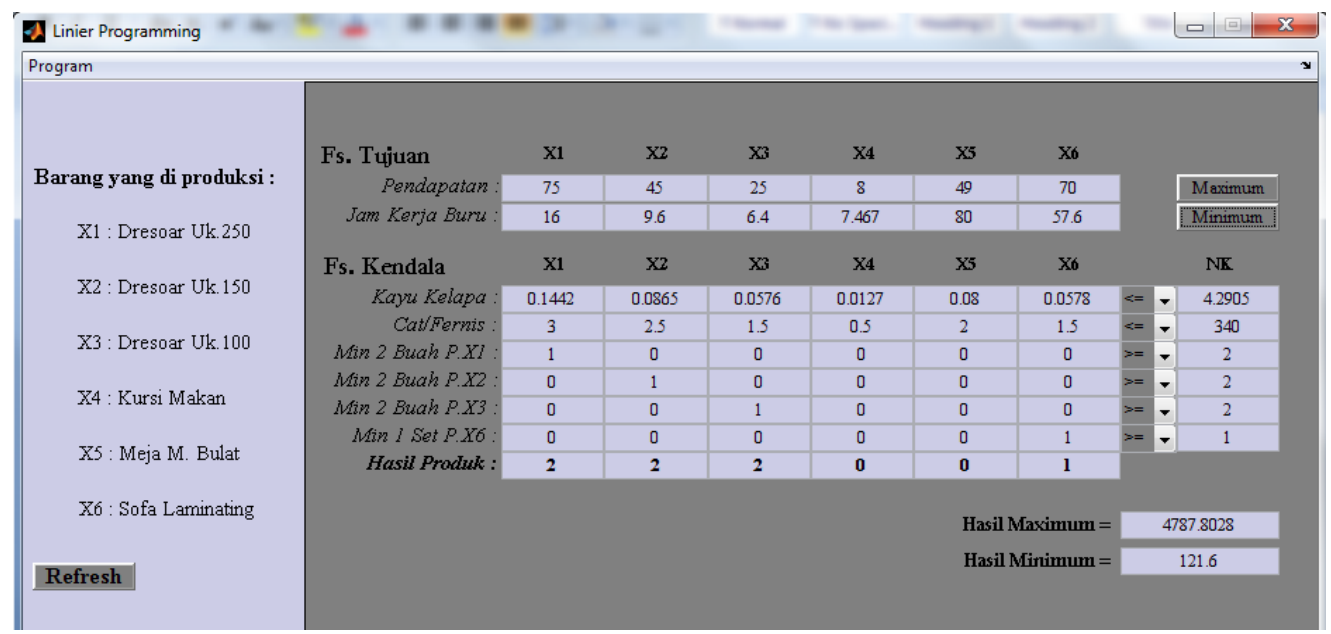

Gambar 8. Form isian dan hasil perhitungan model LP 
Dari kedua proses perhitungan menggunakan linear programming diperoleh hasil maximum pendapatan $Z^{*}=4787,8028$ (Rp.478.780.280) dan hasil minimum waktu kerja buruh adalah $H^{*}=121,6$, hasil dari $Z^{*}$ dan $H^{*}$ yang akan menjadi batasan fungsi keanggotaan fuzzy dari setiap fungsi tujuan.

\subsubsection{Interface Model Fuzzy Goal Programming (FGP)}

Jika keinginan dari pengambil keputusan perusahaan sekurang-kurangnya pendapatan yang akan diperoleh adalah $\bar{Z}=2500$ (Rp.250.000.000) dari pendapatan maximum $Z^{*}=4787,8028$ (Rp.478.780.280) dan waktu kerja buruh maximal $\bar{H}=2400$ jam dari waktu kerja buruh minimal $H^{*}=121,6$ jam, maka model user interface dari persamaan (12) seperti pada gambar 9.

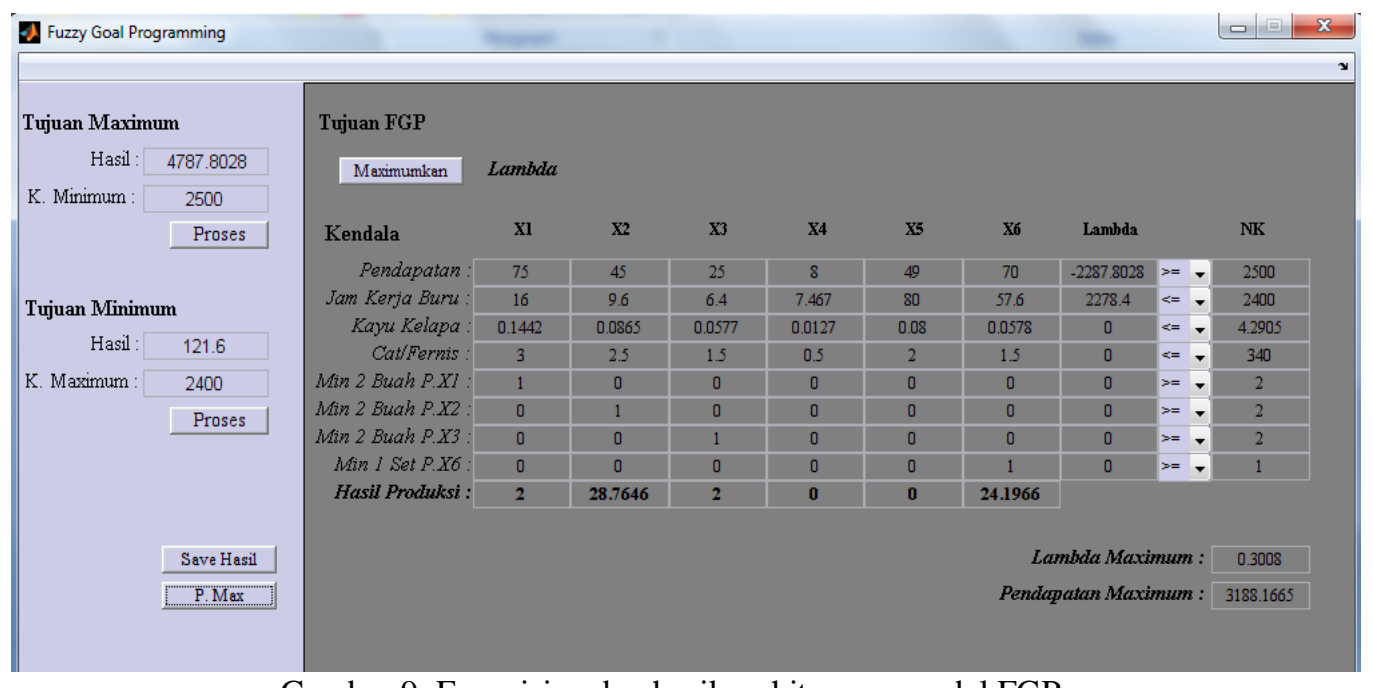

Gambar 9. Form isian dan hasil perhitungan model FGP

Hasil-hasil yang diperoleh tersimpan dengan format (*.txt), sehingga dapat dilihat atau dicetak kembali, tampilan hasil save dapat dilihat pada gambar 10 LP Max, gambar 11 LP Min, dan gambar 12.

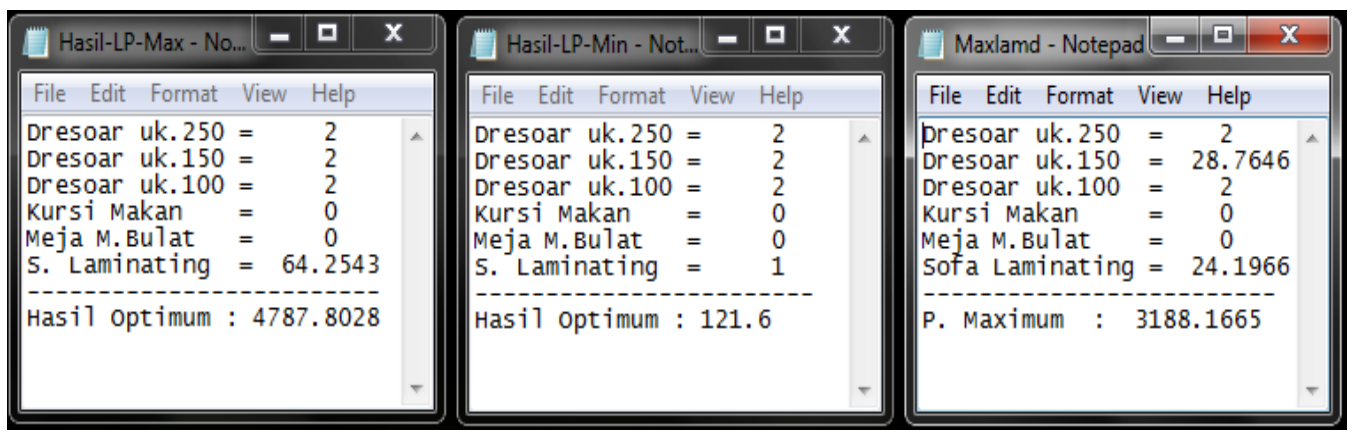

Gambar 10. LP Max $\quad$ Gambar 11. LP Min Gambar 12. Hasil FGP

Dari Hasil perhitungan di peroleh :

$Z^{*} \quad=4787,8028($ Rp. 478.780.280)

$\bar{Z} \quad=2500($ Rp. 250.000 .000$)$

$Z(x)=3188.1665($ Rp. 318.816 .650$)$

$\mu_{Z(x)}=\frac{3188,1665-2500}{4787,8028-2500}=0,3008$, dengan $\bar{Z} \leq Z(x) \leq Z^{*}$

Dari (Tabel 1) pendapatan yang akan diperoleh perusahaan UD. Sinar Sakti adalah Rp.229.400.000, setelah dianalisa dengan metode LP dan FGP diperoleh pendapatan perusahaan adalah sebesar Rp.318.816.650. 


\section{Kesimpulan}

Berdasarkan hasil analisis menggunakan aplikasi yang diperoleh, dapat diambil kesimpulan sebagai berikut :

1. Dengan menggunakan salah satu software matematika dapat dirancang sebuah aplikasi user interface yang dapat menyelesaikan masalah fuzzy goal programming (FGP), dengan fungsi keanggotaan fuzzy yang digunakan linear naik dan turun.

2. Dari hasil analisa LP dan FGP diperoleh, jika pengambil keputusan perusahaan menginginkan pendapatan minimum Rp. 250.000 .000 dan waktu kerja buruh maximum 2400 jam, maka hasil analisa fuzzy goal programming akan diperoleh keuntungan perusahaan sebesar Rp. 318.816.650 dengan produk yang harus dihasilkan perusahaan UD. Sinar Sakti adalah Dresoar uk. 250 sebanyak 2 buah, Dresoar uk. 150 sebanyak 28,7646 buah, Dresoar uk. 100 sebanyak 2 buah, dan Sofa Laminating sebanyak 24,1966 set.

\section{Daftar Pustaka}

[1] Hartati, R.V. 2009. Pendekatan Model Fuzzy Goal Programming dalam Penerapan Pembobotan Prioritas dari Metode Analytical Hierarchy Process (AHP) [skripsi]. FMIPA USU. Medan. http://repository.usu.ac.id/bitstream/123456789/14029/1/09E01172.pdf [04 Nov 2014]

[2] Astiti, M. N. dan K. Andawaningtyas. 2013. Fuzzy Goal Programming pada Perencanaan Produksi Aggregate (studi kasus pada UD. Charisma Kota Mojokerto). FMIPA Universitas Brawijaya. Malang. Jurnal Mahasiswa Matematika.

http://matematika.studentjournal.ub.ac.id/index.php/matematika/article/view/64/67.pdf [04 Nov 2014]

[3] Rindengan, A.J. 2013. Model Fuzzy Goal Programming yang diselesaikan dengan Linear Programming pada Perencanaan Produksi. De Cartesian, 2(2) :27-28.

http://ejournal.unsrat.ac.id/index.php/decartesian/article/view/3236/2780.pdf [04 Nov 2014]

[4] Supranto J.M.A. 2003. Pengantar Matrix. Penerbit PT. Rineka Cipta. Jakarta.

[5] Kusumadewi, S. 2010. Aplikasi Logika Fuzzy untuk Pendukung Keputusan. Penerbit Graha Ilmu. Yogyakarta

[6] Away, G.A. 2010. The Shortcut of MATLAB Programming. Penerbit Informatika. Bandung.

[7] Siswanto. 2007. Operation Research. Penerbit Erlangga. Yogyakarta. 